\title{
Suillus granulatus'tan elde edilen etanolik ekstraktın antioksidan ve antimikrobiyal aktivitelerinin belirlenmesi
}

\author{
Ali Soyuçok ${ }^{1}$, Mahmut Doğantürk², Orhan Yavuz ${ }^{2}$, Cahit Burak Küçükiğgi ${ }^{2}$, Ali Kıyak ${ }^{2}$ \\ ${ }^{1}$ Süt Ürünleri ve Teknolojileri Uygulama ve Araştırma Merkezi, Burdur Mehmet Akif Ersoy Üniversitesi, Burdur/Türkiye \\ ${ }^{2}$ Bilimsel ve Teknoloji Uygulama ve Araştırma Merkezi, Burdur Mehmet Akif Ersoy Üniversitesi, Burdur/Türkiye
}

\section{Anahtar Kelimeler: \\ antimikrobiyal \\ antioksidan}

Suillus granulatus

\begin{abstract}
Key Words:
antimicrobial

antioxidant

Suillus granulatus
\end{abstract}

Geliș Tarihi : 07.09.2021

Kabul Tarihi : 04.11.2021

Yayin Tarihi : 29.04.2022

Makale Kodu: 992073

Sorumlu Yazar:

A. SOYUCOK

(alisoyucok@gmail.com)

ORCID

A. SOYUCOK : 0000-0003-2626-5827

M. DOGÁNTÜRK: 0000-0003-1133-6792

O. YAVUZ: :0000-0002-9263-657X

CB. KÜÇÜKIĞGI : 0000-0001-9317-7013

A. KIYAK :0000-0002-6631-7778

ÖZ

Çalışmamızda, Suillus granulatus mantarının kurumadde ve protein miktarları belirlendikten sonra etanolik ekstraksiyonlarının antioksidan ve antimikrobiyal aktiviteleri araștırılmıștır. Serbest radikal süpürme aktivitesi 1-1 difenil-2-pikrilhidrazil (DPPH) yöntemiyle belirlenirken fenolik madde içeriği yüksek basınçlı sıvı kromatografisi (HPLC) ile tespit edilmiştir. $S$. granulatus ekstraktının antimikrobiyal aktivitesi Staphylococcus aureus, Escherichia coli, Salmonella Typhimurium, Listeria monocytogenes ve Pseudomonas florescens mikroorganizmalarına karşı belirlenmiştir. Çalışmamızda, S. granulatus mantarının kuru madde ve protein miktarları sırasıla \% 37.41 ve $\% 12.84$ bulunmuştur. S. granulatus mantarının antioksidan kapasiteye sahip olduğu ve fenolik asit bakımından en yüksek miktarda bulunan fenolik bileşenlerin sırasıyla ellajik asit, kafeik asit ve gentisik asit olduğu tespit edilmiștir. S. granulatus ekstraktının 64 $\mu \mathrm{g} / \mathrm{ml}$ konsantrasyonunun $S$. aureus ve E. coli gelişimini tamamen inhibe ederken 32 ve $64 \mu \mathrm{g} / \mathrm{ml}$ konsantrasyonlarının S. Typhimurium, L. monocytogenes ve $P$. florescens'in gelişimini baskıladığ1 tespit edilmiştir. Çalışma sonucunda $S$. granulatus mantarının antioksidan kapasiteye sahip olduğu ve $S$. aureus ve E. colìye karşı antimikrobiyal aktiviteye özellik gösterdiği bulunmuştur.

\section{Determination of antioxidant and antimicrobial activities of ethanolic extract from Suillus} granulatus

\begin{abstract}
In this study, dry matter and protein amounts of Suillus granulatus mushroom and antioxidant and antimicrobial activities of ethanolic extraction of $S$. granulatus were investigated. Free radical scavenging activity was determined by the 1-1 diphenyl-2-picrylhydrazil (DPPH) method, while the phenolic content was determined by high pressure liquid chromatography (HPLC). Antimicrobial activity of $S$. granulatus extract was determined against Staphylococcus aureus, Escherichia coli, Salmonella Typhimurium, Listeria monocytogenes and Pseudomonas florescens microorganisms. In our study, dry matter and protein amounts of $S$. granulatus mushroom were found to be $37.41 \%$ and $12.84 \%$, respectively. It was found that $S$. granulatus mushroom had antioxidant capacity and the phenolic components with the highest amount of phenolic acid are ellagic acid, caffeic acid and gentisic acid, respectively. It was determined that 64 $\mu \mathrm{g} / \mathrm{ml}$ concentration of $S$. granulatus extract completely inhibited the growth of $S$. aureus and E. coli, while 32 and $64 \mu \mathrm{g} / \mathrm{ml}$ concentrations suppressed the growth of $S$. Typhimurium, L. monocytogenes and P. florescens. As a result of the study, it was found that the $S$. granulatus had antioxidant capacity and showed antimicrobial activity against S. aureus and E. coli.
\end{abstract}

\section{GİRİŞ}

Nüfusun aşırı düzeyde artması, tarım alanların kentselleştirilmesi, sanayileşme, iklim değişikliği, çevre ve su kirliliği gibi faktörler tarım alanlarında verimin düşmesine neden olmaktadır. Yaşanan bu olumsuz durumların önlenmesi için ucuz, kolay ve sağlıklı alternatif gıda kaynaklarına ihtiyaç duyulmaktadır. Protein, mineral ve vitamin bakımından oldukça zengin olan mantarlar, artan gıda ihtiyacının karşılanmasında önemli besin kaynağıdır. Aynı zamanda doğadan doğrudan toplanabilmesi ve kültür ortamında yüksek verimle üretilmesi ile ekonomik katkı açısından da en önemli gıdaların başında gelmektedir (1).
Birleşmiş Milletler Gıda ve Tarım Örgütünün 2017 yılına ait verilerine göre mantar üretiminde dünyada ilk sıray1 7.8 milyon ton üretim hacmiyle Çin, ikinci sıray1 421 bin ton üretim hacmi ile ABD ve üçüncü sırayı ise 303 bin ton üretim hacmiyle Polonya alırken ülkemiz ise 40 bin tonluk üretimiyle ile 16. sırada yer almaktadır (2). Uygun iklim koşulları, tüketim pazarlarına yakınlık, ucuz hammadde ve insan gücü gibi elverişli koşullara sahip olmasına rağmen Türkiye'de mantar üretimi belirli türlerde yoğunlașması ve tür çeșitliliğin sağlanamaması nedenleri ile ülkemiz büyük mantar üreticisi olan diğer ülkelerle rekabet edebilecek seviyeye gelememiştir. 
Sağlık üzerine etkileri ve içerdiği besin ögeleri bakımından fonksiyonel g1da olarak değerlendirilen mantar (3), özellikle bileșimindeki elzem amino asitler ve minerallere ek olarak fazla miktarda protein içeriğiyle tüketiciler için oldukça önemli bir besin kaynağı olmuştur (4). Mantarın besleyici rolü yanında terapötik etkileri nedeniyle geleneksel sağlik uygulamalarında uzun zamandan beri kullanılmasina neden olmuştur (5). Yapılan çalışmalar mantarın antikanser (6), antioksidan (7), antimikrobiyal (8), oksidatif strese karşı DNA'yı koruyucu (9), kolesterol düşürücü (10), antiinflamatuarsyon (6), antidiyabetik (11), antiviral (12), antihipertansif (13) ve bağışıklık sistemini destekleyici (14) özelliklere sahip olduğunu göstermiştir. Mantarlar sahip oldukları fizyolojik ve teknolojik özellikler g1da endüstrisinin ilgisini çekmektedir. Mantarın köftelerde sululuk kazandırdığ1 ve tekstürün gelişmesine yardımc1 olduğu (15) ve mürekkep balığından üretilen surimilerde kullanımının ise ürünün besleyiciliğini ve fonksiyonelliğini artırdığı ifade edilmiştir (16). Ayrıca emülsifiye et ürünlerinde, mantar ilavesi ile emülsiyon kalitesinin arttı̆̆ 1 (17) ve fosfatların yerini alabileceği (18) yapılan çalışmalarda rapor edilmiştir. Ayrıca buğday ununa mantardan ilave edilen $ß$-glukan buğday ununun diyet lifi miktarının arttırdığı belirtilmiştir (19).

Dünya üzerinde Suillus cinsine ait 50 tür bulunurken Türkiye'de ise Suillus spp. ait 12 adet tür tanımlanmıştır (20). Suillus cinslerinin Suillinin denilen bir fenolik asidi içermekte ve bu fenolik maddenin insan hepatomu HepG2 hücrelerinde güçlü bir apoptoz indükleyicisi olduğu kanıtlanmıştır (21). Ayrıca $S$. collinitus'tan elde edilen metanolik ekstraktının göğüs kanseri hücreleri üzerinde apoptozise neden olduğu ifade edilmiştir (22). Yapılan diğer bir çalışmada ise $S$. luteus'un farklı çözücüler kullanılarak elde edilen ekstraktların insan akciğer, meme, kolon ve mide kanseri hücreleri üzerinde sitotoksik etkiye sahip olduğu ifade edilmiştir (23). S. luteus türü mantarlar sinnamik asit ve protokateşik asit gibi fenolik asitler ile tokoferoller, oleik asit ve linoleik asit gibi biyoaktif yapıları da içermektedir (23). Bu çalışmada $S$. granulatus mantarından elde edilen etanolik ekstraktının antioksidan kapasitesi ve fenolik madde içeriği belirlenerek in vitro koşullarda Gram pozitif ve Gram negative bakterilere karşı antimikrobiyal aktiviteleri araştırılmıştır.

\section{GEREÇ ve YÖNTEM}

Burdur ili Kurna mevkisinde $(1,138 \mathrm{~m})$ toplanan (May1s 2018) mantarların teşhisi Akdeniz Üniversitesi Fen Fakültesi Biyoloji Bölümü Botanik Anabilim Dalı öğretim üyesi Prof. Dr. Hasan AKGÜL tarafindan yapılmıştır. S. granulatus türü mantarın antioksidan, fenolik bileşikler, antimikrobiyal aktivitesi ve protein içeriğinin araştırılması kullanılacak olan mantarlar $40^{\circ} \mathrm{C}$ 'de 24 saat boyunca kurutulduktan mantarlar bir ögütücü (Arzum, Türkiye) yardımıyla toz hale getirilmiş ve $-20^{\circ} \mathrm{C}$ 'de muhafaza edilmiştir.

\section{Kurumadde Analizi}

Kurumadde analizi AOAC (1990)'a göre yapılmıştır (24). Oda sıcaklığına soğutulmuş ve sabit tartıma gelen metal kaplara 5 g mantar örneği tartıldı ve sonra örnek bulunan kaplar $105^{\circ} \mathrm{C} 18$ saat boyunca etüvde (Memmert, Almanya) bekletildi. Sabit tartıma gelen örnekler tartıldı ve aşağıdaki denkleme göre yüzde kuru madde miktarı hesapland1.
\% Kurumadde $=($ Son tartım-dara $) /($ Örnek ağırlı̆̆ $) * 100$

Protein Analizi

S. granulatus mantarındaki protein miktarının belirlenmesi toplam azot miktarından yararlanıldi. Toplam azot miktar1, azot tayin cihaz1 (Dumatherm, Gerhardt, Almanya) kullanılarak belirlendi. Elde edilen toplam azot miktarı mantar için kullanılan azot faktörü olan 4.40 ile çarpılarak \% protein değeri elde edildi (25).

\section{S. granulatus ekstraktimn elde edilmesi}

Öğütülmüş $10 \mathrm{~g}$ mantara $50 \mathrm{ml}$ etanol-su (80:20) ilave edilip 24 saat boyunca manyetik karıştırıcıda 200 rpm'de ekstraksiyon işlemine tabi tutuldu. Mantar ekstraktı Whatman No 40 süzgeç kâğıdı ile süzüldü ardından evaporatör cihazı (Hei-Vap, Heidolph, Almanya) ile etanol uzaklaștırıldı ve elde edilen saf mantar ekstrakt1 $-24^{\circ} \mathrm{C}$ 'de analiz öncesine kadar muhafaza edildi (26).

\section{DPPH Aktivitesinin Belirlenmesi}

Mantar örneklerinin serbest radikal tutma aktivitesinin belirlenmesinde 1-1 difenil-2-pikrilhidrazil (DPPH) radikalinin süpürücü metodu kullanıldı. Mantar ekstraktının 2.5, 5, 10, 12.5 ve $25 \mu \mathrm{g} / \mathrm{ml}$ olmak üzere beş farklı dilüsyonü metanol içerisinde hazırlandı. Bu dilüsyonlardan $1 \mathrm{ml}$ alınarak üzerine $4 \mathrm{ml} \% 0.004$ 'lük DPPH çözeltisi ilave edilip vortekslenerek 30 dakika karanlık ortamda inkübe edildi. Süre sonunda $517 \mathrm{~nm}$ dalga boyunda spektrofotometrede (Perkin Elmer, Lambda35, Amerika Birleşik Devletleri) absorbans değerleri ölçüldü (27).

\section{Fenolike Asit Kompozisyonunun Belirlenmesi}

Mantar örneği $1 \mathrm{ml}$ mobil faz içerisinde çözündürülerek 0.45 mikron filtreden geçirildi. Analizde LC20 AT pompaya sahip DAD (SPD-M20A) dedektörlü Shimadzu Prominence Marka HPLC (Tokyo, Japonya) sistemi kullanıldı. Analiz 1.3 $\mathrm{ml} / \mathrm{dk}$ akış hızında, $20 \mu \mathrm{l}$ enjeksiyon hacminde, $30{ }^{\circ} \mathrm{C}$ kolon sıcaklığında yapıldı. Çalışmada Zorbax C18 (250*4.6 mm, 5 mikron) kolonu kullanıldı. Sonuçlar LC Solution (version 1.25, Japonya) bilgisayar paket programı kullanılarak hesapland. Çalışmada 13 adet fenolik bileşik (sinamik asit, sirinjik asit, 3,4-dihidroksibenzoik asit, vanilik asit, kafeik asit, ferulik asit, 2,5-dihidroksibenzoik asit, epikateşin, ellajik asit, klorojenik asit, kuersetin, rosmarinik asit ve gallik asit) standart olarak kullanıld1 (28).

\section{Antimikrobiyal Aktivitenin Belirlenmesi}

Antimikrobiyal aktivite buyyon dilüsyon yöntemi kullanılarak Minimum İnhibisyon Konsantrasyonu (MIK) değerleri belirlendi. MIKK testleri S. aureus ATCC 25923, E. coli ATCC 35150, S. Typhimurium ATCC 700408, L. monocytogenes RSKK 472 ve P. florescens ATCC 13525 bakterilerinde gerçekleştirildi. Çalışmada yedi farklı ekstrakt konsantrasyonu $(1,2,4,8,16,32$ ve $64 \mu \mathrm{g} / \mathrm{ml})$ içeren Mueller Hinton Broth II (Merck, Almanya) besiyeri ve ekstrakt içermeyen Mueller Hinton Broth II besiyeri kullanıldı. Hazırlanan besiyeriler düz tabanlı bir mikroplakaya (Flat bottom, Corning®, Amerika Birleşik Devletleri) her bir kuyucuğa $180 \mu$ l olarak dağıtıldı. TSA (Merck, Almanya) geliştirilen taze bakteri kültürlerin tür- 
biditesi densitometre yardımıyla (Den-1 Densitometer, Biosan, Letonya) \%0.9 NaCl içerisinde $0.5 \mathrm{McF}$ arland yoğunluğunda süspansiyon hazırland1. Hazırlanan bakteri süspansiyonlarından $20 \mu \mathrm{l}$ mikroplakadaki besiyeriler üzerine inoküle edildi. İnokülasyon sonucu mikroplakalar $37^{\circ} \mathrm{C}$ derece sicaklıkta 24 saat inkübe edildi. İnkübasyon sonucunda mikroplaka okuyucusunda (Epoch, BioTek Amerika Birleşik Devletleri) 600 nm dalga boyunda okuma yapıldı (29).

\section{Istatistiksel Analiz.}

Çalışmada yapılan bütün analizler 3 paralelli olarak gerçekleştirilmiş olup sonuçlar MS Excel 2016 (Microsoft, Amerika Birleşik Devletleri) paket programı kullanılarak \% dağılım testi analizleri gerçekleştirildi. Sonuçlar ortalama \pm standart sapma olarak verildi.

\section{BULGULAR}

S. granulatus ait kurumadde miktar1 \% $37.41 \pm 0.73$, protein

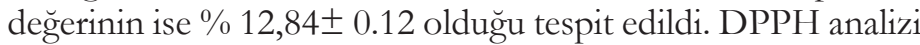
sonucunda, $S$. granulatus ekstraktının DPPH radikalini süpürme aktivitesi 175. $64 \mu \mathrm{mol} \mathrm{TE} / \mathrm{g}$ kuru ağırlık olarak tespit edildi. Antimikrobiyal aktivite sonuçlarına göre $S$. granulatus ekstraktinin $64 \mu \mathrm{g} / \mathrm{mL}$ konsantrasyonunda E. coli ve $S$. aureus inhibe olurken $16 \mu \mathrm{g} / \mathrm{mL}$ 'den daha yüksek konsantrasyonları L. monocytogenes, $S$. Typhimurium ve $P$. florescens gelişimlerini baskıladığ1 bulundu.

\section{TARTIŞMA}

\section{Kurumadde Analizi Sonucu}

Dikeman vd. (30) 10 dakikalık pişirme işleminin Agaricus bisporus'un ağırlı̆̆ının \% 30 azalmasına neden olduğunu raporlamışlardır. Suillus spp.'nin kurumadde değerinin belirlendiği iki farklı çalışmada, Suillus spp.'nin kurumadde miktarı \% 7 (31) ve \% 8.62 (32) olduğu ifade edilmiştir. Diğer mantarlara kıyasla düşük kurumadde ağırlığına sahip Suillus mantarı besin ögeleri bakimindan Boletus edulis, Cantharellus cibarius ve Romaria botrytis'a benzerlik göstermektedir (33). Bulgularımıza benzer olan bir çalışmada (34), araştırmacılar S. luteus'un kurumadde miktarını \% 45 olarak tespit edilmiştir.

\section{Protein Analizi Sonucu}

2001 yılında yapılan bir çalışmada ise S. granulatus mantarının protein içeriğinin \% 24.68 olduğu belirtilmiştir (32). 30 adet mantarın protein içeriğinin belirlendiği bir çalışmada (35), araştırmacılar mantarların protein içeriklerinin \% 18.3264.70 aralığında olduğu ve Suillus cinsine ait örneklerin protein miktarının ise \% 31.16-40.73 arasında değiștiğini ifade etmișlerdir. Başka bir çalışmada 8 cins arasından en düşük protein içeriğinin (\% 16) S. granulatus'a ait olduğu ve kültüre edilmiş/ edilmemiş mantarlar için protein değerinin \% 16-35 aralığında değiştiği ifade edilmiştir (31). Benzer bir çalışmada ise S. luteus'un protein miktarının \% 11 olduğu ve bu değer çalışmamızla kıyasla daha düşük olduğu belirlenmiştir (34). Suillus spp. cinsine ait mantarlarının protein miktarlarındaki bu değişkenlik hasat öncesi (hasat zamanı, bulunduğu yer ve iklim koşulları) ve pişirme (su miktarının uzaklaşması) gibi bazı parametrelerden kaynaklanmaktadır $(34,35)$.

\section{DPPH Analizi Sonucu}

Yapılan çalışmalar diğer mantarlara kıyasla Suillaceae ailesine ait üyeleri daha düşük antioksidan aktivite gösterdiğini raporlamışlardır $(33,36)$. Suillus ekstraktının antioksidan aktivitesi içermiş olduğu fenolik bileşenlerden kaynaklanmaktadır (37). Jaworska vd. (34) taze $S$. luteus mantarınin metanol ile ekstraksiyonu sonucunda elde ettiği ekstraktın DPPH aktivitesini 3.48 mmol TE olduğunu tespit etmişlerdir. Yapılan bir çalışmada Suillus ekstraktının etanol ve metanol çözücülerindeki DPPH aktiviteleri araştırılmıştır (37). Araştırmacılar en yüksek DPPH aktivitesi sırasıyla metanol ve etanol çözücülerinde bulmuş ve Suillus ekstraktının BHT'den daha yüksek antioksidan aktiviteye sahip olduğunu ifade etmişlerdir. İki Suillus türünün antioksidan kapasitesinin karşılaştırıldığı bir çalışmada, S. collinitus ve $S$. mediterraneenis cinslerinin $\mathrm{IC}_{50}$ değerleri farklılik gösterdiği en yüksek antioksidan aktivite $S$. mediterraneenis cinsinde tespit edilmiştir (36).

\section{Fenolik Asit Analizi Sonucu}

Çalışmamızda Suillus ekstraktında kuersetin, rutin, vanilik ve ferulik asit tespit edilmemiştir. Suillus ekstraktının 70 ppm konsantrasyonda ellajik asit içerdiği ve daha sonra en yüksek bulunan fenolik yapiların kafeik (7.52 ppm) ve gentisik asit (4.55 ppm) olduğu tespit edilmiștir. Suillus ekstraktında tespit edilen epikateşin asit, klorojenik asit, gallik asit, narginin asit, monohidrobenzoik asit, p-kumarik asit ve sinamik asit konsantrasyonlarının 0 ile 1 ppm arasında değişken olduğu tespit edilmiştir. Yapılan bir çalışmada 9 farklı cins mantar olmak üzere toplam 32 yenilebilir yabani mantarın fenolik madde içeriği araştırılmıştır (38). Araştırmacılar S. bellini ve S. granulatus türlerinde bulunan başlıca fenolik bileşenin şikimik asit olduğunu belirlemişlerdir. Başka bir çalışmada S. collinitus'un etanolik ekstraktında $5.2 \mathrm{ppm}$ protokateşik asit, $14.1 \mathrm{ppm}$ hidrobenzoik asit ve $1.3 \mathrm{ppm}$ sinamik asit bulunduğunu ifade edilmiştir (22). Benzer çalışmalarda, S. granulatus türünde bulunan başlica fenolik bileşen hidroksibenzoik asit olduğu tespit edilirken (39), S. luteus türünde kafeik asit olduğu ifade edilmiştir (34). Reis vd. (40) yaptıkları çalışmada Sırbistan ve Portekiz'de bulunan $S$. granulatus türünün fenolik bileşen kompozisyonunu araştırmışlardır. Araştırmacılar Portekiz'de bulunan $S$. granulatus türünün daha yüksek fenolik madde içerdiğini ve gallik asit, hidroksibenzoik asit ve sinamik asit bakımından daha zengin olduğunu ifade etmişlerdir. Yapılan benzer bir çalışmada, S. granulatus'un \% 20'lik metanol ekstraktında fumarik asit (48.38 ppm) ve kateşin hidrat (16.59 ppm) bulunan en yüksek fenolik maddeler olduğu ifade edilmiştir (41).

\section{Antimikrobiyal Aktivite Sonuclar}

Yapılan MİK testi sonuçlarına göre test edilen S. aureus ve E. coli suşları üzerinde $64 \mu \mathrm{g} / \mathrm{ml}$ konsantrasyonda tamamen inhibisyon gerçekleştiği tespit edilmiştir. Diğer üç test edilen bakteride ise bu çalışma için en yüksek konsantrasyon olan $64 \mu \mathrm{g} /$ $\mathrm{mL}$ değerinde bakteri gelişiminin baskılandığı gözlemlenmektedir. Diğer mikroorganizmalara kıyasla $S$. aureus ve $P$. florescens suşlarında Suillus ekstraktı miktarı artıkça optik densitelerde artış meydana geldiği bulundu. Meydana gelen artıs mikroorganizmanın $S$. granulatus ekstraktının varlığına karşı gösterdiği bir direnç mekanizması olarak düşünülmüştür. Tüm bakteriler için 
$16 \mu \mathrm{g} / \mathrm{ml}$ konsantrasyon değerinde ise üremenin baskilanmaya başladığı konsantrasyon olarak değerlendirilebilir (Şekil 1).

Yamaç ve Bilgili tarafindan 2006 yılında yayınlanan bir çalışmada $S$. collitinus türünün antimikrobiyal aktivitesi incelenmiştir. Bu çalışmada araştırmamıza benzer olarak E. coli (250 $\mu \mathrm{g} / \mathrm{ml}), S$. Typhimurium $(125 \mu \mathrm{g} / \mathrm{ml})$, P. aeruginosa (Tespit edilememiş) ve $S$. aureus $(25 \mu \mathrm{g} / \mathrm{ml})$ MIK değerleri tespit edilmiştir (42). Bu çalışmada E. coli, $S$. Typhimurium ve $P$.

\section{SONUÇ}

Çalışmamızda Burdur'da bulunan S. granulatus'un antioksidan ve antimikrobiyal özelliği araştırılmıştır. Elde ettiğimiz bulgular $S$. granulatus mantarının serbest radikal süpürme aktivitesine sahip olduğu ve fenolik madde içeriği bakımından literatürden farklı olarak ellajik asit ve gentisik asit miktarlarının yüksek olduğu bulunmuştur. Antimikrobiyal aktivite verilerine göre $64 \mu \mathrm{g} / \mathrm{ml} S$. granulatus ekstraktı konsantrasyonu $S$. aureus

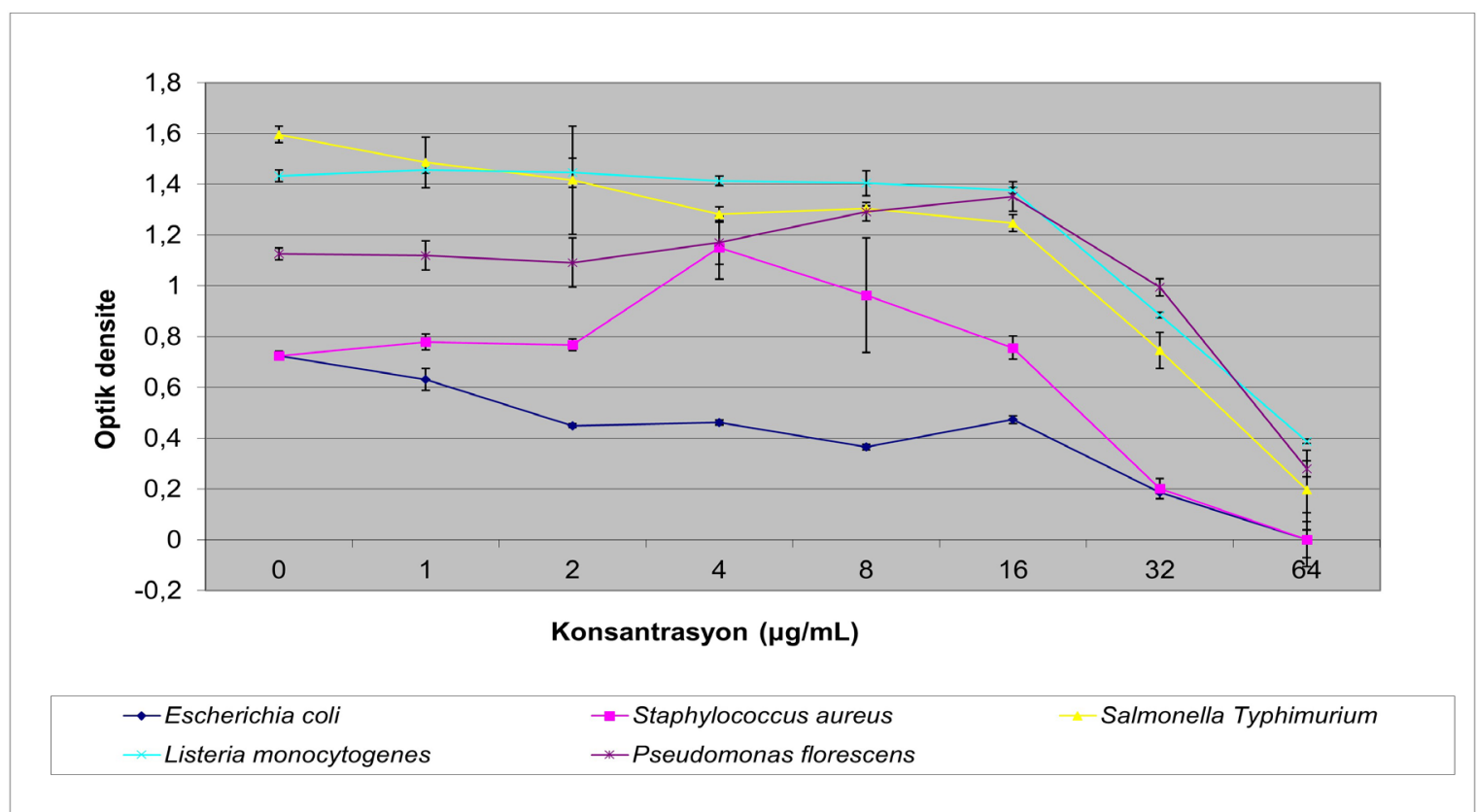

Şekil 1. Suillus granulatus ekstraktının bazı patojen bakteriler üzerindeki etkileri

Figure 1. Effects of Suillus granulatus extract on some pathogen bacteria

aeruginosa için çalışmamıza göre çok daha düşük antimikrobiyal etki gözlemlenmiştir. E. coli ve $S$. Typhimurium için bu kadar yüksek farkların sebebi kullanılan bakteri suşlarının aynı olmaması veya kullanılan mantar türünün aynı olmaması olarak açıklanabilir. Çalışmada kullanılan ve antimikrobiyal etkinin tespit edilemediği $P$. aeruginosa yerine çalışmamızda kullanılan $P$. florescens türünde antimikrobiyal etki tespit edilmiştir. Burada aynı cinse ait farklı türler üzerinde antimikrobiyal etkinin değişken olabileceği sonucu gözlemlenmiştir. S. aureus için ise her iki çalışmada da aynı bakteri suşu kullanılmasına rağmen sonuçlar arasında fark vardır. Burada önemli etkinin mantar türünden kaynaklandığ1 düşünülmektedir. Shen vd. (43), Suillus cinsi mantarlarda yaptığ1 antimikrobiyal çalışmada $L$. monocytogenes türünde antimikrobiyal etki tespit edememiştir. Çalışmamızda ise L. monocytogenes türünün gelişimi düşürdüğü gözlemlenmiştir. Klančnik vd. (44), Slovenya'dan toplanan yabani mantar örnekleri yapılan çalışmada E. coli türü için MİK değerleri $S$. variegatus ve $S$. granulatus türlerinde sirasıyla 95 ve 62 $\mu \mathrm{g} / \mathrm{ml}$ olarak tespit edilmiştir. $S$. granulatus türü çalışmamızla benzer sonuç gösterirken $S$. variegatus türü daha yüksek MIKK değeri vermiștir. E. coli için farklı bölgelerde benzer sonuçlar çıkması antimikrobiyal etki ile bölgesel farklılık arasında bir ilişki olmadı̆̆ını göstermiştir. ve E. coli gelişimini tamamen inhibe ettiği tespit edilmiştir. 16 $\mu \mathrm{g} / \mathrm{ml}$ 'den daha yüksek $S$. granulatus ekstraktı konsantrasyonlan1 S. Typhimurium, L. monocytogenes ve P. florescens gelişimini baskıladığ1 tespit edilmiştir. Çalışmamız sonucunda $S$. granulatus mantarının gida, kozmetik ve farmakoloji alanları için alternatif bir doğal kaynak olabileceği düşünülmektedir

\section{BEYANNAMELER}

\section{Etik onay}

Çalışmada herhangi bir deney hayvanı kullanılmaması nedeniyle etik kurul raporuna gerek bulunmamıştır.

\section{Finansman}

$\mathrm{Bu}$ araştırma, kamu, ticari veya kar amacı gütmeyen sektörlerdeki finansman kuruluşlarından herhangi bir özel hibe almamıştır.

\section{Veri kullanılabilirliği}

Bu çalışmanın bulgularını destekleyen veriler makul talep üzerine sorumlu yazardan temin edilebilir. 


\section{Çıkar çatışması}

Yazarlar herhangi bir çıkar çatışması olmadığını beyan eder.

\section{Yazar Katkıları}

Fikir, Kavram ve Tasarım: MD

Veri Toplama ve Analiz: AS, MD, OY, CBK, AK

Makalenin Yazımı: AS, MD, OY

Eleştirel İnceleme: AS

\section{Teşekkür}

Laboratuvar alt yapısının kullanıldığı Burdur Mehmet Akif Ersoy Üniversitesi, Bilimsel ve Teknoloji Uygulama ve Araştırma Merkezi'ne teşekkür eder ve mantar türünün teşhisi sağlayan Akdeniz Üniversitesi Fen Fakültesi Biyoloji Bölümü Botanik Anabilim Dalı öğretim üyesi Prof. Dr. Hasan AKGÜL'e şükranlarımızı sunarız.

\section{KAYNAKLAR}

1. Akgül H, Sevindik M, Akata I, Altuntaş D, Bal C, Doğan M. Macrolepiota procera (Scop.) Singer. Mantarının Ağır Metal İçeriklerinin ve Oksidatif Stres Durumunun Belirlenmesi. Süleyman Demirel Üniversitesi Fen Bilimleri Enstitüsü Dergisi. 2016; $20(3)$ : 504-508.

2. FAO (Food and Agricultural Organization). 2020. http://www.fao.org/3/y5489e/y5489e00.htm, (Erişim tarihi: 07.01.2021)

3. Akgül H, Sevindik M, Coban C, Alli H, Selamoglu Z. New aproaches in traditional and complementary alternative medicine practices: Auricularia auricula and Trametes versicolor. J Tradit Med Clin Naturop. 2017; 6(239): 1-4.

4. Sevindik M, Bal C, Akgül H. Comparison of Antioxidant Potentials of the Wild and Cultivated Forms of Edible Pleurotus ostreatus and Agaricus bisporus Mushrooms.Türk Yaşam Bilimleri Dergisi. 2018; 3(2):263-266.

5. Öztürk A, Çopur Ö U. Mantar bileşenlerinin teröpatik etkileri. Bahçe. 2009; 38(1), 19-24. 2009.

6. Ma L, Chen H, Dong P, Lu X. Anti-inflammatory and anticancer activities of extracts and compounds from the mushroom Inonotus obliquus. Food Chem. 2013; 139(1-4): 503-508.

7. Cheung L M, Cheung P C, Ooi V E. Antioxidant activity and total phenolics of edible mushroom extracts. Food Chem. 2003; 81(2): 249-255.

8. Alves M J, Ferreira I C, Dias J, Teixeira V, Martins A, Pintado M. A review on antimicrobial activity of mushroom $(\mathrm{Ba}-$ sidiomycetes) extracts and isolated compounds. Planta med. 2012; 78(16): 1707-1718.

9. Park Y K, Lee H B, Jeon E J, Jung H S, Kang M H. Chaga mushroom extract inhibits oxidative DNA damage in human lymphocytes as assessed by comet assay. Biofactors. 2004; $21(1-4):$ 109-112.

10. Bobek P, Ginter E, Jurčovičová M, Kuniak L. Choles- terol-lowering effect of the mushroom Pleurotus ostreatus in hereditary hypercholesterolemic rats. Ann Nutr Metab. 1991: 35(4): 191-195.

11. Friedman M. Mushroom polysaccharides: chemistry and antiobesity, antidiabetes, anticancer, and antibiotic properties in cells, rodents, and humans. Foods. 2016; 5(4): 80.

12. Teplyakova T V, Psurtseva N V, Kosogova T A, Mazurkova N A, Khanin V A, Vlasenko V A. Antiviral activity of polyporoid mushrooms (higher Basidiomycetes) from Altai Mountains (Russia). Int j med mushrooms. 2012; 14(1).

13. Talpur N A, Echard B W, Fan A Y, Jaffari O, Bagchi D, et al. Antihypertensive and metabolic effects of whole Maitake mushroom powder and its fractions in two rat strains. Mol cell biochem. 2002; 237(1-2): 129-136.

14. Liu F, Ooi V E C, Liu W K, Chang S T. Immunomodulation and antitumor activity of polysaccharide-protein complex from the culture filtrates of a local edible mushroom, Tricholoma lobayense. Gen Pharmacol. 1996; 27(4): 621-624.

15. Chun S, Chambers I V, Edga R, Chambers D. Perception of pork patties with shiitake (Lentinus edode P.) mushroom powder and sodium tripolyphosphate as measured by Korean and United States consumers. J Sens Stud. 2005; 20(2): 156-166.

16. Im Chung S, Kim S Y, Nam Y J, Kang M Y. Development of surimi gel from king oyster mushroom and cuttlefish meat paste. Food Sci Bio. 2010; 19(1): 51-56.

17. Kurt A, Gençcelep H. Enrichment of meat emulsion with mushroom (Agaricus bisporus) powder: Impact on rheological and structural characteristics. J Food Eng. 2018;237: 128-136.

18. Choe J, Lee J, Jo K, Jo C, Song M, Jung S. Application of winter mushroom powder as an alternative to phosphates in emulsion-type sausages. Meat Sci. 2018; 143: 114-118.

19. Kim J, Lee S M, Bae I Y, Park H G, Gyu Lee H, et al. (1-3) (1-6)- $\beta$-Glucan-enriched materials from Lentinus edodes mushroom as a high-fibre and low-calorie flour substitute for baked foods. J Sci Food Agric. 2011; 91(10): 1915-1919.

20. Sarwar S, Khalid A N. Diversity and phylogeny of suillus (suillaceae; boletales; basidiomycota) from coniferous forests of pakistan. Int J Agric Biol. 2014; 16(3): 489-497.

21. Liu F Y, Luo K W, Yu Z M, Co N N, Wu S H, Wu P $\mathrm{W}$, et al. Suillin from the mushroom Suillus placidus as potent apoptosis inducer in human hepatoma HepG2 cells. Chem Bio Interact. 2009; 181: 168-174.

22. Vaz J A, Ferreira I C F R, Tavares C, Almeida G M, Martins A, Vasconcelos H M. Suillus collinitus methanolic extract increases p53 expression and causes cell cycle arrest and apoptosis in a breast cancer cell line, Food Chem. 2012; 135(2): 596-602,

23. Reis F S, Heleno S A, Barros L, Sousa M J, Martins A, Santos-Buelga C. Toward the antioxidant and chemical charac- 
terization of mycorrhizal mushrooms from Northeast Portugal. J Food Sci. 2011; 76: 824-830.

24. AOAC. 1990. Official Methods of Analyses. Association of Official Analytical Chemist. IAC, Arlington, VA, USA.

25. Doğantürk M, Gürlek M E. Yetiştiricilikte Alternatif Gübre Olarak En Çok Tercih Edilen İki Salyangoz (Helix aspersa ve Achatina fulica) Gübresinin Fiziksel ve Kimyasal Özellikleri. Mehmet Akif Ersoy Üniversitesi Fen Bilimleri Enstitüsü Dergisi. 2019; 9(2): 144-150. 2019.

26. Selani M M, Contreras-Castillo C J, Shirahigue L D, Gallo C R, Plata-Oviedo M, Montes-Villanueva N D. Wine Industry Residues Extracts as Natural Antioxidants in Raw and Cooked Chicken Meat During Frozen Storage. Meat Sci. 2011; 88: 397-403.

27. Erdoğan S, Soylu M K, Başer K H C. Bazı yabani mantarların antioksidan özellikleri. Nevşehir Bilim ve Teknoloji Dergisi. 2017; 6: 254-260.

28. Gomes T, Caponio F, Alloggio V. Phenolic compounds of virgin olive oil:influence of paste preperation techniques. Food Chem 1999; 64: 203-209.

29. Demirtas A, Ozturk H, Sudagidan M, Keyvan E, Yavuz O, Gulay O Y, et al. Effects of commercial aldehydes from green leaf volatiles (green odour) on rumen microbial population and fermentation profile in an artificial rumen (Rusitec). Anaerobe. 2019; 55: 83-92.

30. Dikeman C L, Bauer L L, Flickinger E A, Fahey G C. Effects of stage of maturity and cooking on the chemical composition of select mushroom varieties. J Agric Food Chem. 2005; 53: 1130-1138.

31. Ouzouni P, Riganakos K. Nutritional value and metal content profile of Greek wild edible fungi. Acta Alimentaria, 2007;36(1): 99-110.

32. Petrovska B B. Protein fraction in edible Macedonian mushrooms. Europ Food Res Tech. 2001; 212(4): 469-472.

33. Pereira E, Barros L, Martins A, Ferreira I C. Towards chemical and nutritional inventory of Portuguese wild edible mushrooms in different habitats. Food Chem. 2012; 130(2): 394403.

34. reG, Pogoń K, Bernaś E, Skrzypczak A, Kapusta I. Vitamins, phenolics and antioxidant activity of culinary prepared Suillus luteus (L.) Roussel mushroom. LWT. 2014; 59(2): 701 706.

35. Uzun Y, Gen H, Tun Y, Demirel K. Determination of protein and nitrogen fractions of wild edible mushrooms. Asian Journal of Chemistry. 2009; 21(4): 2769. 2009.

36. Heleno S A, Barrosn L, Sousa M J, Martins A, Ferreira I C F R. Tocopherols composition of Portuguese wild mushrooms with antioxidant capacity. Food Chem. 2010; 119:14431450 .

37. Aytar E C, Akata İ, Açık L. Antioxidant, Antimicrobial and Ant1-Proliferative Activity Of Suillus Luteus (L.) Roussel
Extracts. Journal of Faculty Of Pharmacy Of Ankara University. 2020; 44(3): 373-387.

38. Ribeiro B, Rangel J, Valentao P, Baptista P, Seabra R M, Andrade P B. Contents of carboxylic acids and two phenolics and antioxidant activity of dried Portuguese wild edible mushrooms. J Agric Food Chem. 2006; 54(22): 8530-8537.

39. Ribeiro B, Andrade P B, Silva B M, Baptista P, Seabra R M, Valentão P. Comparative study on free amino acid composition of wild edible mushroom species. J Agric Food Chem. 2008; 56(22): 10973-10979.

40. Reis F S, Stojković D, Barros L, Glamočlija J, Ćirić A, Soković M, et al. Can Suillus granulatus (L.) Roussel be classified as a functional food. Food \& function. 2014; 5(11): 28612869.

41. Çayan F, Deveci E, Tel-Çayan G, Duru ME. Identification and quantification of phenolic acid compounds of twenty-six mushrooms by HPLC-DAD. Journal of Food Measurement and Characterization.2020; 14(3): 1690-1698.

42. Yamaç M, Bilgili F. Antimicrobial activities of fruit bodies and/or mycelial cultures of some mushroom isolates. Pharm biol. 2006; 44(9): 660-667.

43. Shen H S, Shao S, Chen J C, Zhou T. Antimicrobials from mushrooms for assuring food safety. Compr Rev Food Sci Food Saf. 2017; 16(2): 316-329.

44. Klančnik A, Megušar P, Sterniša M, Jeršek B, Bucar F, Smole Možina S, et al. Aqueous Extracts of Wild Mushrooms Show Antimicrobial and Antiadhesion Activities against Bacteria and Fungi. Phytother Res. 2017; 31(12): 1971-1976. 